Original article

DOI: 10.1515/aiht-2017-68-2905

\title{
Lycopene restores trace element levels in ochratoxin A-treated rats
}

\author{
Saziye Sezin Palabiyik ${ }^{1}$ Pinar Erkekoglu², Murat Kızlgun ${ }^{3}$, Gonul Sahin ${ }^{4}$, and \\ Belma Kocer-Gumusel ${ }^{2}$
}

\begin{abstract}
Ataturk University, Faculty of Pharmacy, Department of Toxicology, Erzurum ${ }^{1}$, Hacettepe University, Faculty of Pharmacy, Department of Toxicology, Ankara 2, Diskapi Children's Hospital, Department of Biochemistry, Ankara ${ }^{3}$, Eastern Mediterranean University, Faculty of Pharmacy, Department of Toxicology, Mersin ${ }^{4}$, Turkey
\end{abstract}

[Received in November 2016; Similarity Check in November 2016; Accepted in May 2017]

\begin{abstract}
This study was designed to investigate the in vivo effects of ochratoxin A(OTA) and/or lycopene on the levels of selenium, zinc, and copper in the liver, kidneys, and testes of male Sprague-Dawley rats. The rats were treated with OTA $\left(0.5 \mathrm{mg} \mathrm{kg}^{-1} \mathrm{day}^{-1}\right)$ and/or lycopene $\left(5 \mathrm{mg} \mathrm{kg}^{-1} \mathrm{day}^{-1}\right)$ by gavage for 7 or 14 days. Trace element levels were measured by atomic absorption spectrometry. OTA significantly lowered selenium $(20 \%$ in the liver, $17 \%$ in the kidney, and $40 \%$ in the testis), zinc (24\% in the liver, $23 \%$ in the kidney, and $26 \%$ in the testis), and copper levels (40\% in the liver and $10 \%$ in the kidney). Lycopene alone did not affect the trace element levels in any of the organs. In combination with OTA, however, it significantly restored liver, kidney, and testis selenium and zinc levels compared to the group treated with OTA alone. Our results have confirmed that depletion of trace elements in different organs is one of the mechanisms of action of OTA. They also suggest that lycopene interferes with this depleting effect and restores trace element levels, the implications of which need to be further investigated.
\end{abstract}

KEY WORDS: copper; kidney; liver; mycotoxins; selenium; testis; zinc

Ochratoxins are a family of mycotoxins produced by several food-borne species of the genera Aspergillus and Penicillium as secondary metabolites. These toxins are ochratoxin A (OTA), B, and C, and OTA is the most abundant and the most toxic member of the ochratoxin family (1). It can contaminate a variety of food commodities like cereals, vegetables, dried fruits, spices, coffee, nuts, fermented beverages, and medicinal plants. Consumption of such food results in chronic exposure $(1,2)$. OTA is a potent kidney carcinogen in animals $(3,4)$ and is arguably involved in the Balkan endemic nephropathy and urinary tract tumours in humans $(5,6)$. However, a direct causeeffect relation has not yet been established, and the mechanism of OTA carcinogenicity remains to be clarified in humans, even though animal research has given sufficient evidence of its carcinogenic properties (7).

Researchers have proposed several underlying mechanisms of OTA toxicity, such as the inhibition of protein synthesis, membrane lipid peroxidation, and DNA damage (8-10). Our earlier studies (11-13) showed that OTA caused oxidative stress, lipid peroxidation, oxidative DNA damage, and apoptosis in rat kidney and liver, but we could not pinpoint the exact toxicity mechanism. There are only

Correspondence to: Prof Belma Koçer Gumusel, Hacettepe University, Faculty of Pharmacy, Department of Toxicology, 06100 Ankara, Turkey, E-mail:belmagumusel@yahoo.com; bgiray@hacettepe.edu.tr a few reports investigating the effects of OTA on trace elements or vice versa (14-16).

Lycopene is the most prevalent antioxidant carotenoid in the Western diet. It is present in tomatoes, watermelon, pink grapefruit, and several other red fruits (16). The consumption of tomatoes and/or tomato products is associated with increased lycopene blood levels and reduced oxidative damage of lipids, proteins, and DNA (17). Recent studies showed that consumption of lycopene-containing food, especially tomato products and lycopene supplements, was associated with a decreased risk of chronic complex conditions, ranging from cancer to cardiovascular diseases (18-20). However, little is known about the effects of lycopene on trace element status.

In tissues such as liver, kidney, and testis, trace elements have substantial roles in preserving tissue and cellular integrity. The levels of trace elements have particular importance in maintaining tissue homeostasis, as they prevent the toxic action of different chemicals due to their presence in several intracellular antioxidant components. Changes in trace element levels can affect the cellular redox state, which may result in cell disruption and tissue damage (21). Furthermore, their levels affect the expression and synthesis of several antioxidant enzymes, superoxide dismutase (SOD), glutathione peroxidases (GPxs), and thioredoxin reductases (TrxRs) in particular. For example, selenium (Se) deficiency may lead to dysfunctional immune response, cardiovascular disease, neurodegeneration, and 
finally cancer (22-26). Zinc ( $\mathrm{Zn})$ is the cofactor of more than 300 enzymes. Copper $(\mathrm{Cu})$ is common in organic complexes known as metalloproteins, which act as antioxidant enzymes. Together with iron $(\mathrm{Fe}), \mathrm{Cu}$ is important for the activity of cytochrome c oxidase, an enzyme which is required for aerobic respiration whereas with $\mathrm{Zn}$, it affects the activity of $\mathrm{Cu}, \mathrm{Zn}$-SOD, an enzyme that catalyses the breakdown of superoxides (27).

This study in male Sprague-Dawley rats was designed to a) investigate the effects of OTA and/or lycopene on trace element ( $\mathrm{Se}, \mathrm{Zn}$, and $\mathrm{Cu}$ ) levels in the liver, kidney, and testis; b) evaluate OTA toxicity in relation to the changes in trace element levels; and c) determine protective effects of lycopene against OTA toxicity.

To the best of our knowledge, this is the first study in which such effects have been investigated in vivo.

\section{MATERIALS AND METHODS}

\section{Chemicals and reagents}

All chemicals were purchased from Sigma-Aldrich (St. Louis, MO, USA) or Merck Co (Darmstadt, Germany). Lycopene was a gift from Micro-Gen (Ankara, Turkey).

\section{Animals and treatment}

Male Sprague-Dawley rats $(<200 \mathrm{~g})$ were supplied from the Hacettepe University Experimental Animals Laboratory. The animals were housed in plastic cages with stainlesssteel grid tops under standard laboratory conditions (temperature $23{ }^{\circ} \mathrm{C}$; humidity $50 \%$, and the 12 -hour light and dark cycle) and had free access to standard laboratory chow and drinking water. The study was approved by the Hacettepe University Ethics Committee.

The dose chosen for OTA treatment was $1 / 40$ of the median lethal dose $\left(\mathrm{LD}_{50}\right)(24)$. The lycopene dosing was based on the literature. Limpens et al. (28) observed that daily supplementation with lycopene at $5 \mathrm{mg} \mathrm{kg}^{-1}$ of body mass through oral gavage was well tolerated and did not change mean body weight in nude mice. In addition, Breinholt et al. (29) demonstrated that a 14-day lycopene treatment at $5 \mathrm{mg} \mathrm{kg}^{-1} \mathrm{day}^{-1}$ for 14 days peaked the antioxidant enzyme activities in rats. Cavusoglu et al. (30) treated rats with 5 or $10 \mathrm{mg} \mathrm{kg}^{-1}$ day $^{-1}$ lycopene in combination with mercury $(\mathrm{Hg})$ and found that lycopene lowered $\mathrm{Hg}$ cytotoxicity at both doses.

The study consisted of six groups of six animals each. The control group $(\mathrm{C} 7)$ received $1 \mathrm{~mL}$ of corn oil containing $10 \%$ DMSO by intra-gastric lavage for 7 days. The lycopene control group I (L7) received daily intra-gastric lycopene doses of $5 \mathrm{mg} \mathrm{kg}^{-1}$ bw for 7 days. The lycopene control group II (L14) received the same doses for 14 days. The OTA group (OTA) received daily intra-gastric OTA doses of $0.5 \mathrm{mg} \mathrm{kg}^{-1} \mathrm{bw}$ for 14 days. The OTA plus lycopene 7 group (OTA+L7) received OTA (in the same doses as above) for 14 days and lycopene (in the same doses as above) for the last seven days of treatment. The OTA and lycopene 14 group (OTA+L14) received the combination in the above doses for 14 days.

Lycopene was dissolved in DMSO and later scaled to the required volume with corn oil. The rats were weighed at baseline (before receiving the first dose) and at the end of the (one or two-week) treatment, $24 \mathrm{~h}$ after which they were anaesthetised with thiopental and decapitated and their kidneys, testes, and liver removed.

\section{Preparation of tissue homogenates and determination of trace element levels}

For wet digestion, $100 \mathrm{mg}$ of each tissue (liver, kidney, or testis) was taken into a tube containing $1 \mathrm{~mL}$ of $30 \%$ $\mathrm{HNO}_{3}$ and heated at $110^{\circ} \mathrm{C}$ for at least one hour. This process is applied to digest the organic material and remove the inorganic part. The samples were then cooled to room temperature and kept at $-80{ }^{\circ} \mathrm{C}$ until analysis.

Trace elements were determined with atomic absorption spectrometry (AAS). For $\mathrm{Se}$ and $\mathrm{Cu}$ we used Zeeman background correction AAS (SpectrAA 240Z, Agilent, Santa Clara, CA, USA) and for Zn fast sequential AAS (SpectrAA 240FS, Agilent). Both spectrometers were equipped with a graphite tube atomizer (GTA 120, Agilent).

Stock solutions for $\mathrm{Se}, \mathrm{Zn}$, and $\mathrm{Cu}$ were prepared by dissolving $1 \mathrm{~g}$ of high-purity metals in nitric acid and filling the volume up to $1000 \mathrm{~mL}$ with double-distilled water. When kept in polyethylene bottles at $-20{ }^{\circ} \mathrm{C}$, they can be used for at least 3 months. From these stock solutions, we prepared the basic set of $100 \mathrm{~mL}$ standard solutions containing $5 \mathrm{~mL}$ of hydrochloric acid to construct analytical curves. To prepare calibration curves for the standards we used the following concentrations: $0,0.5,1,2,5,10,25$, and $50 \mu \mathrm{g} \mathrm{mL}^{-1}$ for Se; 1, 5, 10, 50, 100, and $200 \mu \mathrm{g} \mathrm{mL}^{-1}$ for $\mathrm{Zn}$; and $0,0.25,0.5,1,2,4,8$, and $10 \mu \mathrm{g} \mathrm{mL}^{-1}$ for $\mathrm{Cu}$. Optical densities were read at $196 \mathrm{~nm}, 213.9 \mathrm{~nm}$, and 324.7 $\mathrm{nm}$, respectively. To verify the assay accuracy, standard solutions were run on every $10^{\text {th }}$ test. Trace element levels were calculated with the Spectr AA software (Agilent).

Recoveries from blank samples spiked with $1 \mu \mathrm{g} \mathrm{mL}^{-1}$ Se, $25 \mu \mathrm{g} \mathrm{mL}^{-1} \mathrm{Zn}$, or $5 \mu \mathrm{g} \mathrm{mL}^{-1} \mathrm{Cu}$ (30 samples for each element) were (mean \pm SD): $91 \pm 4.2 \%$ for Se, $94 \pm 3.1 \%$ for $\mathrm{Zn}$, and $95 \pm 2.4 \%$ for $\mathrm{Cu}$. The variation coefficients for between-run precisions were $10.40 \pm 0.74 \%$ for Se, $9.12 \pm 1.14 \%$ for $\mathrm{Cu}$, and $11.04 \pm 2.25 \%$ for $\mathrm{Zn}$. For withinday precisions these coefficients were $7.28 \pm 1.14 \%$ for Se, $10.14 \pm 1.97 \%$ for $\mathrm{Zn}$, and $11.25 \pm 3.41 \%$ for $\mathrm{Cu}$.

The limit of detection (LOD) for Se, $\mathrm{Zn}$, and $\mathrm{Cu}$ was $0.025 \mu \mathrm{g} \mathrm{mL}^{-1}, 0.027 \mu \mathrm{g} \mathrm{mL}^{-1}$, and $0.025 \mu \mathrm{g} \mathrm{mL}^{-1}$, respectively.

\section{Statistical analysis}

The results are expressed as means \pm standard deviation (SD). The differences between the groups were analysed 
with the Statistical Package for Social Sciences program (v. 17.0, SPSS, Chicago, IL, USA) using the Kruskal-Wallis one-way analysis of variance and then Mann-Whitney U test. The $\mathrm{P}$ values $<0.05$ are considered statistically significant.

\section{RESULTS AND DISCUSSION}

\section{Liver trace element levels}

In OTA-treated rats, all trace element levels decreased significantly ( $\mathrm{Se} \sim 20 \%, \mathrm{Zn} \sim 24 \%$, and $\mathrm{Cu} \sim 40 \%$ ) compared to the control group $(\mathrm{P}<0.05)$ (Table 1). Similar to our findings, the in vitro study by Zheng et al. (15) in human hepatoma (HepG2) cells established that a 12-hour exposure to OTA lowered intracellular Zn levels to $80.67 \%$ of the control cell levels. Adding Zn, however, counteracted OTA-induced DNA damage.

Lycopene treatment made no significant changes regardless of the treatment duration. Our results are in accordance with Watanabe et al. (31), who also showed that lycopene diet supplementation did not affect serum and liver Zn levels compared to control.

Given with OTA, however, lycopene in our study significantly restored $\mathrm{Se}$ and $\mathrm{Cu}$ levels compared to the OTA group, but the 7-day treatment failed to recover $\mathrm{Cu}$ and $\mathrm{Zn}$ to control levels. Zinc was fully recovered only with the 14-day lycopene treatment while $\mathrm{Cu}$ levels remained significantly lower than control (Table 1).

Judging by the findings reported by Banji et al. (32), lycopene shows better (synergistic) effects if combined with Zn supplements. We can assume that higher lycopene levels would have induced higher $\mathrm{Zn}$ transport to liver in the presence of OTA.

A similar explanation may also be valid for $\mathrm{Cu}$; either higher levels of lycopene or longer supplementation periods with lycopene are needed to restore $\mathrm{Cu}$ levels to control ones. However, longer exposure to carotenoids at doses higher than expected in normal diet may not result in beneficial effects, which needs to be investigated further on a rat model.

\section{Kidney trace element levels}

Similar to the liver, kidney trace element levels dropped significantly in the OTA group compared to control (Se by $\sim 17 \%$, Zn by $\sim 23 \%$, and $\mathrm{Cu}$ by $\sim 10 \%$ ), and lycopene given alone did not affect them. In combination with OTA it significantly restored $\mathrm{Se}$ and $\mathrm{Cu}$ levels, but not $\mathrm{Zn}$ compared to the OTA group, even though it did increase Zn levels by $\sim 12 \%$ (Table 2 ). Again, we can conclude that either higher levels of lycopene or longer supplementation

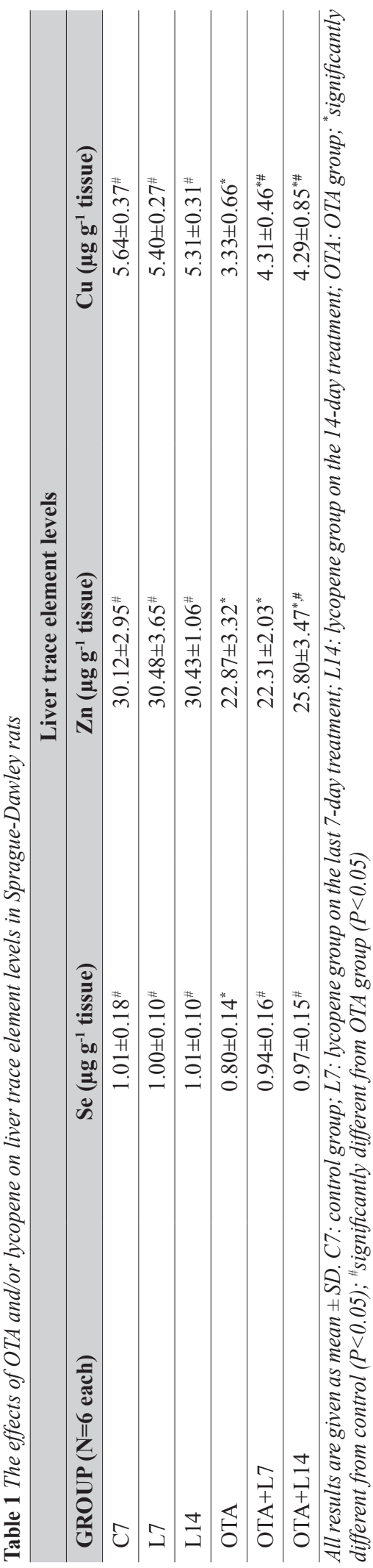
is needed to restore $\mathrm{Zn}$ levels to normal in the kidney. 


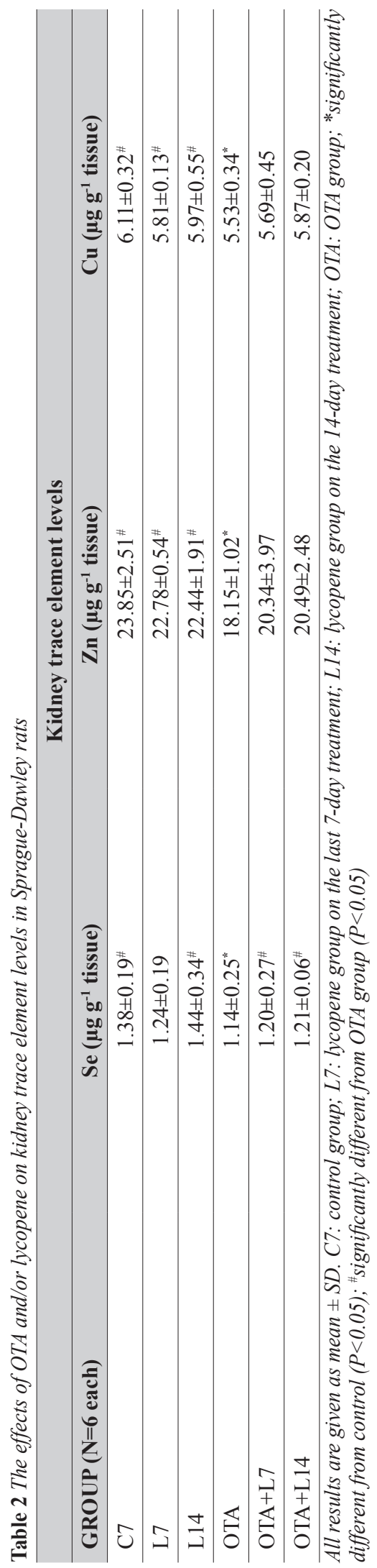

\section{Testicular trace element levels}

As in the other organs, OTA treatment significantly lowered Se $(\sim 47 \%)$ and $\mathrm{Zn}(\sim 26 \%)$ but did not affect the $\mathrm{Cu}$ levels (Table 3). Malekinejad et al. (34) suggested that OTA could cause reproductive abnormalities, and our findings suggest that decreasing Zn levels may be involved, as $\mathrm{Zn}$ has a critical role in sperm production (35).

Lycopene alone, again, did not affect the trace element levels, but in combination with OTA it significantly restored Se $(\sim 47 \%$ in the OTA+L 7 group and $\sim 79 \%$ in the OTA+L14 group) and Cu levels ( $21 \%$ in the OTA+L7 group and $\sim 8 \%$ in the OTA+L14 group) compared to the OTA group. It was not, however, effective in counteracting OTA-induced drop in testicular Zn levels (Table 3).

The protective roles of selenium, copper, and zinc against OTA toxicity have been well established in research conducted so far, and lycopene seems to prevent their depletion.

Atroshi et al. (36) have established that OTA reduces selenoenzyme activity and that Se supplementation (in combination with vitamin E) compensates for this effect. Lycopene in our study seems to have achieved the same, but not through compensation but rather by preventing Se depletion. It is quite likely that it improves selenoenzyme expression as described by Gan et al. (37) in porcine kidney 15 (PK15) cells.

As for $\mathrm{Cu}$ and $\mathrm{Zn}$, the effects of lycopene against OTA toxicity are not that clear-cut, especially in the testes. $\mathrm{Cu}$ levels in rats receiving OTA+lycopene rose above those observed in the control and lycopene-alone groups (Table 3 ). This may be the consequence of lycopene changing the oxidative/antioxidative equilibrium. Future studies might look into how it affects this equilibrium.

It also remains to elucidate why lycopene was not efficient in counteracting Zn-lowering OTA effects in all organs. Perhaps because OTA had more severe effects on $\mathrm{Zn}$ than on Se and $\mathrm{Cu}$ levels. What we can conclude from these findings is that $\mathrm{Zn}$-deficient individuals may suffer detrimental reprotoxic effects, both due to OTA toxicity and $\mathrm{Zn}$ deficiency. However, it remains for the future studies to prove it.

\section{CONCLUSION}

Being the first in vivo study of OTA effects on trace elements and of the lycopene action against OTA toxicity, our study is limited in many ways. It investigates treatment with one OTA dose, one antioxidant (lycopene), and only three trace elements. Even so, it has confirmed that at least one of the mechanisms underlying OTA toxicity is its lowering of trace element levels in different organs. It has also shown that lycopene improves trace element distribution in various tissues after OTA exposure. People who take sufficient amounts of vitamin A analogues are therefore better protected from the toxic effects of OTA. 


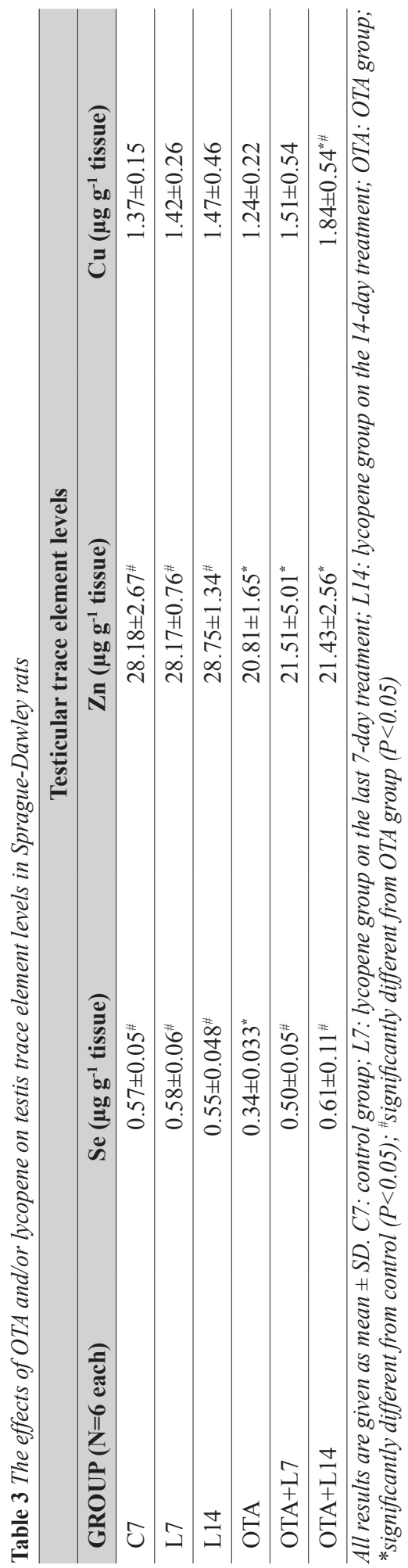

This protection should be enhanced with a well-balanced diet that includes vitamins, trace elements, and minerals.

\section{Conflicts of interest}

The authors declare no conflicts of interest.

\section{REFERENCES}

1. Ashiq S, Hussain M, Ahmad B. Natural occurrence of mycotoxins in medicinal plants: a review. Fungal Genet Biol 2014;66:1-10. doi: 10.1016/j.fgb.2014.02.005

2. European Food Safety Authority (EFSA). Opinion of the scientific panel on contaminants in the food chain on a request from the commission related to ochratoxin $\mathrm{A}$ in food. Question $N^{\circ}$ EFSA-Q-2005-154 EFSA J 2006;365:1-56.

3. Cavin C, Delatour T, Marin-Kuan M, Fenaille F, Holzhauser D, Guignard G, Bezencon C, Piguet D, Parisod V, RichozPayot J, Schilter B. Ochratoxin A-mediated DNA and protein damage: roles of nitrosative and oxidative stresses. Toxicol Sci 2009;110:84-94. doi: 10.1093/toxsci/kfp090

4. Marin-Kuan M, Ehrlich V, Delatour T, Cavin C, Schilter B. Evidence for a role of oxidative stress in the carcinogenicity of ochratoxin A. J Toxicol 2011;2011:645361. doi: $10.1155 / 2011 / 645361$

5. Pfohl-Leszkowicz A. Ochratoxin A and aristolochic acid involvement in nephropathies and associated urothelial tract tumours. Arh Hig Rada Toksikol 2009;60:465-83. doi: 10.2478/10004-1254-60-2009-2000

6. Stefanovic V, Polenakovic M. Fifty years of research in Balkan endemic nephropathy: where are we now? Nephron Clin Pract 2009;112:c51-6. doi: 10.2478/10004-1254-602009-2000

7. International Agency for Research on Cancer (IARC). Some Naturally Occurring Substances: Food Items and Constituents, Heterocyclic Aromatic Amines and Mycotoxins. Monograph on the Evaluation of Carcinogenic Risks to Humans. Vol. 56. Lyon: IARC; 1993.

8. Renzulli C, Galvano F, Pierdomenico L, Speroni E, Guerra MC. Effects of rosmarinic acid against aflatoxin B1 and ochratoxin-A-induced cell damage in a human hepatoma cell line (Hep G2). J Appl Toxicol 2009;24:289-96. doi: 10.1002/ jat.982

9. Mally A, Volkel W, Amberg A, Kurz M, Wanek P, Eder E, Hard G, Dekant W. Functional, biochemical, and pathological effects of repeated oral administration of ochratoxin A to rats. Chem Res Toxicol 2005;18:1242-52. doi: 10.1021/tx049651p

10. Liu J, Wang Y, Cui J, Xing L, Shen H, Wu S, Lian H, Wang J, Yan X, Zhang X. Ochratoxin A induces oxidative DNA damage and G1 phase arrest in human peripheral blood mononuclear cells in vitro. Toxicol Lett 2012;211:164-71. doi: 10.1016/j.toxlet.2012.03.800

11. Aydin S, Palabiyik SS, Erkekoglu P, Sahin G, Basaran N, Giray BK. The carotenoid lycopene protects rats against DNA damage induced by Ochratoxin A. Toxicon 2013;73:96-103. doi: 10.1016/j.toxicon.2013.07.004

12. Palabiyik SS, Erkekoglu P, Zeybek ND, Kizilgun M, Sahin G, Giray B. Ochratoxin A causes oxidative stress and cell death in rat liver. World Mycotoxin J 2012;5:377-84. doi: 10.3920/WMJ2012.1446 
13. Palabiyik SS, Erkekoglu P, Zeybek ND, Kizilgun M, Baydar DE, Sahin G, Giray BK. Protective effect of lycopene against ochratoxin A induced renal oxidative stress and apoptosis in rats. Exp Toxicol Pathol 2013;65:853-61. doi: 10.1016/j. etp.2012.12.004

14. Steele JA, Davis ND, Diener UL. Effect of zinc, copper, and iron on ochratoxin A production. Appl Microbiol 1973:25;84749. PMCID: PMC380922

15. Zheng J, Zhang Y, Xu W, Luo, Y, Hao, J, Shen, XL, Yang X, Li X, Huang K. Zinc protects HepG2 cells against the oxidative damage and DNA damage induced by ochratoxin A. Toxicol Appl Pharmacol 2013;268:123-31. doi: 10.1016/j. taap.2013.01.021

16. Story EN, Kopec RE, Schwartz SJ, Harris GK. An update on the health effects of tomato lycopene. Annu Rev Food Sci Technol 2010;1:189-210. doi: 10.1146/annurev. food.102308.124120

17. Agarwal S, Rao AV. Tomato lycopene and its role in human health and chronic diseases. CMAJ 2000;163:739-44. PMCID: PMC80172

18. Giovannucci E, Rimm E, Liu Y, Stampfer MJ, Willett WC. A prospective study of tomato products, lycopene, and prostate cancer risk. J Natl Cancer Inst 2002;94:391-98. doi: 10.1093/jnci/94.5.391

19. Riccioni G, Mancini B, Di Ilio E, Bucciarelli T, D’Orazio N. Protective effect of lycopene in cardiovascular disease. Eur Rev Med Pharmacol Sci 2008;12:183-90. PMID: 18700690

20. Wood LG, Garg ML, Powell H, Gibson PG. Lycopene-rich treatments modify noneosinophilic airway inflammation in asthma: proof of concept. Free Radic Res 2008;42:94-102. doi: 10.1080/10715760701767307

21. Osredkar J, Sustar N. Copper and zinc, biological role and significance of copper/zinc imbalance. J Clin Toxicol 2001;S3:001. doi:10.4172/2161-0495.S3-001

22. Hoffmann PR, Berry MJ. The influence of selenium on immune responses. Mol Nutr Food Res 2008;52:1273-80. doi: $10.1002 / \mathrm{mnfr} .200700330$

23. Liu $\mathrm{H}, \mathrm{Xu} \mathrm{H}$, Huang K. Selenium in the prevention of atherosclerosis and its underlying mechanisms. Metallomics 2017;9:21-37. doi: 10.1039/c6mt00195e

24. Pitts MW, Byrns CN, Ogawa-Wong AN, Kremer P, Berry MJ. Selenoproteins in nervous system development and function. Biol Trace Elem Res 2014;161:231-45. doi: 10.1007/s12011-014-0060-2

25. Micke O, Schomburg L, Buentzel J, Kisters K, Muecke R. Selenium in oncology: from chemistry to clinics. Molecules 2009;14:3975-88. doi: 10.3390/molecules 14103975

26. Reeves MA, Hoffmann PR. The human selenoproteome: recent insights into functions and regulation. Cell Mol Life Sci 2009;66:2457-78. doi: 10.1007/s00018-009-0032-4
27. Abreu IA, Cabelli DE. Superoxide dismutases - a review of the metal-associated mechanistic variations. Biochim Biophys Acta 2010;1804:263-74. doi: 10.1016/j. bbapap.2009.11.005

28. Limpens J, Schröder FH, de Ridder CM, Bolder CA, Wildhagen MF, Obermüller-Jevic UC, Krämer K, van Weerden WM. Combined lycopene and vitamin $\mathrm{E}$ treatment suppresses the growth of $\mathrm{PC}-346 \mathrm{C}$ human prostate cancer cells in nude mice. J Nutr 2006;136:1287-93. PMID: 16614418

29. Breinholt V, Lauridsen ST, Daneshvar B, Jakobsen J. Doseresponse effects of lycopene on selected drug-metabolizing and antioxidant enzymes in the rat. Cancer Lett 2000;154:20110. doi: 10.1016/S0304-3835(00)00401-8

30. Cavusoglu K, Oruc E, Yapar K, Yalcin E. Protective effect of lycopene against mercury-induced cytotoxicity in albino mice: pathological evaluation. J Environ Biol 2009;30(Suppl 5):807-14. PMID: 20143710

31. Watanabe S, Kitade Y, Masaki T, Nishioka M, Satoh K, Nishino H. Effects of lycopene and Sho-saiko-to on hepatocarcinogenesis in a rat model of spontaneous liver cancer. Nutr Cancer 2001;39:96-101. doi: 10.1207/ S15327914nc391_13

32. Banji D, Banji OJ, Reddy M, Annamalai AR. Impact of zinc, selenium and lycopene on capsaicin induced mutagenicity and oxidative damage in mice. J Trace Elem Med Biol 2013;27:230-5. doi: 10.1016/j.jtemb.2013.01.001

33. Huggins KA, Navara KJ, Mendonça MT, Hill GE. Detrimental effects of carotenoid pigments: the dark side of bright coloration. Naturwissenschaften 2010;97:637-44. doi: 10.1007/s00114-010-0679-6

34. Malekinejad H, Mirzakhani N, Razi M, Cheraghi H, Alizadeh A, Dardmeh F. Protective effects of melatonin and Glycyrrhiza glabra extract on ochratoxin A-induced damages on testes in mature rats. Hum Exp Toxicol 2011;30:110-23. doi: 10.1177/0960327110368416

35. Uriu-Adams JY, Keen CL. Zinc and reproduction: effects of zinc deficiency on prenatal and early postnatal development. Birth Defects Res B Dev Reprod Toxicol 2010;89:313-25. doi: 10.1002/bdrb.20264

36. Atroshi F, Rizzo A, Sankari S, Biese I, Westermarck T, Veijalainen P. Liver enzyme activities of rats exposed to ochratoxin A and T-2 toxin with antioxidants. Bull Environ Contam Toxicol 2000;64:586-92. doi: 10.1007/ s001280000043

37. Gan F, Xue H, Huang Y, Pan C, Huang K. Selenium alleviates porcine nephrotoxicity of ochratoxin A by improving selenoenzyme expression in vitro. PLoS One 2015;10(3):e0119808. doi: 10.1371/journal.pone.0119808 


\section{Likopen obnavlja razine elemenata u tragovima u štakora izloženih okratoksinu A}

Svrha ovoga in vivo istraživanja bila je utvrditi djelovanje okratoksina A (OTA) i/ili likopena na razine selenija, cinka i bakra u jetri, bubrezima i testisima mužjaka štakora Sprague-Dawley. Štakori su primali OTA $\left(0,5 \mathrm{mg} \mathrm{kg}^{-1} \mathrm{dan}^{-1}\right) \mathrm{i} / \mathrm{ili}$ likopen $\left(0,5 \mathrm{mg} \mathrm{kg}^{-1} \mathrm{dan}^{-1}\right)$ gavažom u trajanju od 7 odnosno 14 dana. Elementi u tragovima izmjereni su atomskom apsorpcijskom spektrometrijom. OTA je značajno snizila razine selenija (20 \% u jetri, $17 \%$ u bubregu te $40 \%$ u testisu), cinka (24\% u jetri, $23 \%$ u bubregu te $26 \%$ u testisu) i bakra ( $40 \%$ u jetri te $10 \%$ u bubregu). Kad je davan sam, likopen ni u jednom organu nije utjecao na razine elemenata u tragovima. Međutim, u kombinaciji s OTA-om značajno je obnovio razine selenija i cinka u jetri, bubregu i testisu u usporedbi sa skupinom izloženom samo okratoksinu A. Naši rezultati potvrđuju da je jedan od mehanizama djelovanja okratoksina A nestanak elemenata u tragovima u pojedinim organima. Također upućuju na to da likopen sprečava takvo djelovanje i obnavlja razine elemenata u tragovima. Buduća bi istraživanja trebala rasvijetliti implikacije ovih saznanja.

KLJUČNE RIJEČI: bakar; bubreg; cink; jetra; mikotoksini; selenij; testis 